\title{
The Export Growth of Pakistan: A Decomposition Analysis
}

\author{
AZHAR MAHMOOD and NAEEM AKHTAR
}

\begin{abstract}
The Constant Market Share Analysis of export growth is used here to capture the world trade effect, the commodity composition effect, the market distribution effect and the competitiveness effect for the periods: 1984-85-1988-89 and 1988-89-1992-93. The results show that Pakistan has maintained her export share in the world market. The market distribution and competitiveness of Pakistani exports have improved significantly between the two periods under study. However, the concentration of Pakistani exports into traditional commodities, whose world demand remained sluggish, has offset the positive contribution of effective market distribution and improved competitive strengths to a large extent. A restructuring of exports (from traditional to non-traditional), an increase in the variety of exports, search for new fast growing markets and an improvement in the economic and political environment are suggested to enhance the export growth of Pakistan in future.
\end{abstract}

\section{INTRODUCTION}

Pakistan's economy is typically characterised by a large resource (savinginvestment) gap, government budget deficit, and current account imbalance. The reliance on international trade and foreign capital inflows has become crucial to sustain and enhance the pace of economic growth in the scarcity and misutilisation of the domestic resources. The international trade has proven to be the engine of economic growth at international level. One of the major reasons for the rapid growth of the East Asian countries is their excellent export performance. These countries liberalised the international trade and offered many incentives for the establishment and development of their export sectors. Pakistan's exports grew at an average annual growth rate of 8.0 percent per annum and accounted for 9.5 percent of GDP in the 1980s. The share of exports in GDP increased to 13.0 percent in the 1990s (1990-91-1994-95).

In order to accelerate the growth of exports, Government of Pakistan offered a number of export incentives in the mid-1980s. The establishment of two export processing zones, compensatory rebates on various items, excise and sales tax rebates, tax relief for exporters of machinery and capital goods, easing the imports of raw materials for export oriented industries, improvements in the institutional arrangements for quality control and marketing and export credit guarantee scheme

Azhar Mahmood and Naeem Akhtar are both Research Economist at the Pakistan Institute of Development Economics, Islamabad. 
etc. were among these incentives. In 1988, Government of Pakistan launched its Macro-economic Adjustment Program to improve the fiscal policy, trade policy and deregulation process. Prior to that, in 1982, Pakistan moved from a fixed exchange rate system to a managed floating exchange rate system with an objective to make her exports more competitive in the foreign markets. It is quite relevant now to examine the effect of these changes on the competitiveness of Pakistan's exports.

The purpose of this paper is to analyse changes in the export performance of Pakistan for the periods between 1984-85-1988-89 and 1988-89-1992-93, using the Constant Market Share Analysis of export growth. This analysis decomposes the actual change in exports into four effects, namely: (i) the world trade effect (WTE); (ii) the commodity composition effect (CCE); (iii) the market distribution effect (MDE); and (iv) the competitiveness effect (CE). The paper is organised as follows. Section II describes the theoretical framework and data specification issues. Results are discussed in Section III and conclusions and policy recommendations are presented in Section IV.

\section{THEORETICAL FRAMEWORK AND DATA SPECIFICATION}

The Constant Market Share Analysis (CMSA), initially used by Tyszynski (1951), rests on the assumption that a country's export share in the world market remains constant overtime. Tyszynski (1951) used this analysis to study changes in the market shares of countries exporting manufactured goods from 1899-1950. The analysis was further developed and extended by Leamer and Stern (1970) and Richardson (1971). Considering that the exports from a country are differentiated by destination as well as by commodity groups, the actual export growth of a country between any two time periods using the CMSA can be decomposed as:

$$
\begin{aligned}
& V_{2}-V_{1}=r^{*} V_{1}+\sum^{n}\left(r_{i}-r\right)^{*} V_{i}+\sum^{n} \sum^{m}\left(r_{i j}-r_{i}\right) * V_{i j} \\
& i=1 \quad i=1 \quad j=1 \\
& +\sum_{i=1}^{n} \sum_{j=1}^{m}\left(V_{i j^{\prime}}-V_{i j}-r_{i j} V_{i j}\right) \quad \ldots \quad \ldots \quad \ldots
\end{aligned}
$$

where:

$V_{1}$ : Value of a particular country's exports in the base period.

$V_{2}$ : Value of a particular country's exports in the final period.

$V_{2}-V_{1}$ : Change in the total value of exports between two time periods.

$V_{i j}$ : Value of a country's export of commodity $i$ to country $j$ in the base period.

$V_{i j^{\prime}}$ : Value of a country's export of commodity $i$ to country $j$ in the final period.

$V_{i}$ : Value of a country's export of commodity $i$ in the base period. 
$R$ : Percentage increase in total world exports between two time period.

$r_{i}$ : Percentage increase in world exports of commodity $i$ between two time periods.

$R_{i j}$ : Percentage increase in world exports of commodity $i$ to country $j$ between two time periods.

$N$ : Number of commodities.

$M$ : Number of markets.

The four expressions on the right-hand side of the identity (1) decompose the actual change in exports of a country into four effects which are explained respectively as: ${ }^{1}$ (i) "the world trade effect" $\left(r^{*} V_{1}\right)$, which relates any change in the actual exports of a country to the general rise in the world exports. The positive sign of this effect indicates that a country has maintained her share of exports in the foreign markets vis-à-vis the world and vice versa; (ii) "the commodity composition effect" ( $\sum^{n}$ $\left.\left(r_{i}-r\right) * V_{i}\right)$, measures the extent to which a country's exports are concentrated in the commodities with growth rates more favourable than the world average. The positive sign of this effect imply that a particular commodity composition of exports is favourable and markets for those commodity groups are growing relatively fast; (iii) "the market distribution effect" $\left(\sum^{n} \sum^{m}\left(r_{i j}-r_{i}\right) * V_{i j}\right)$, measures whether the markets chosen for exports by a country are growing relatively fast or are stagnant. The positive sign of this effect indicates that a country's exports are concentrated in relatively faster growing markets; and (iv) "the competitiveness effect" is basically a residual reflecting the difference between the actual export growth and the growth that would have occurred if a country had maintained her share of exports of each commodity to each country.

The interpretation of the competitiveness effect is not so straight forward. It captures the influence of a number of factors including relative price and non-price factors such as domestic policies. ${ }^{2}$ It is not always possible to quantify all these factors. The positive sign of this effect reflects that a country had maintained its share and improved competitiveness in the foreign markets.

Despite its main advantage of decomposing the actual export growth into commodity, market distribution and competitiveness effects, a drawback of CMSA is that it is sensitive to the choice of the base period and the level of disaggregation of the commodities and markets.

The CMSA has been used by Fleming and Tsiang (1958); Balassa (1962); Stern (1967) and Tiwari (1986) to examine changes in export shares and competitiveness. For Pakistan, Little et al. (1970); Hussain (1974) and Mahmood (1981) have used this analysis to analyse Pakistan's export performance. However,

${ }^{1}$ See Leamer and Stern (1970) for an explanation of these effects.

${ }^{2}$ See Leamer and Stern (1970) and Richardson (1971) for detailed discussion of the competitiveness effect. 
the analysis has not been used recently for Pakistan. Mahmood's analysis covered the period 1972-76. Since then there has been drastic changes in the domestic policies to promote exports and Pakistan moved from a fixed exchange rate system to a managed float. The present study examines the changes in the competitiveness of Pakistan's exports during a more liberal trade regime.

Using the CMSA, the export growth of Pakistan has been examined for the periods between 1984-85-1988-89 and 1988-89-1992-93. Twelve commodities are chosen for the analysis: clothing, cotton fabrics, textile yarn and thread, articles of textile materials, cotton, leather and manufactures of leather, rice, floor coverings and tapestries, synthetic fabrics, toys, games and sporting goods, fish and fish preparations, and medical instruments. The choice of these commodities is made on the basis of their importance in the total value of exports of Pakistan. ${ }^{3}$ The share of each commodity was one or more than one percent in total exports of Pakistan during the period under study (1984-85, 1988-89, 1992-93). For the destination of exports, twenty two foreign markets have been chosen. These markets are: USA, Germany, Hong Kong, UK, Japan, UAE, Saudi Arabia, France, Italy, Korea, Netherlands, Canada, Bangladesh, Belgium, Spain, Australia, Singapore, Thailand, Sweden, Switzerland, Sri Lanka and India. More than seventy five percent of Pakistan's exports were destined to these countries during the period under study.

\section{RESULTS}

The results of the CMSA to examine the export performance of Pakistan are presented in Tables 1 and 2. Total exports increased by US\$ 1848.11 million between 1984-85 and 1988-89 while the increase between 1988-89 and 1992-93 was US\$ 1702.69 million. The smaller increase in the latter period may be due to currency devaluation, inappropriate domestic policies (political instability, large fiscal deficits, inflation etc.) and an unfavourable global environment, such as a fall in the demand for Pakistani exports etc. Almost 65 percent of the increase in exports between 1984-85 and 1988-89 is attributed to a general rise in the world exports. The positive sign of (WTE) effect in both periods under study indicates that Pakistan has maintained her share of exports in foreign markets vis-à-vis the world.

The increase in Pakistan's exports is not accounted for by favourable commodity composition for both periods. The commodity composition effect is negative in both periods and even worsened in the latter period (see Table 1). ${ }^{4}$ The commodity composition of Pakistan's export has not changed much overtime. Pakistani exports remained concentrated mainly in the traditional commodities such as raw cotton, rice and semi-finished textile products. Table 3 presents the ranking of

${ }^{3}$ The share of these commodities in total exports was 79, 89 and 93 percent, respectively, for the periods 1984-85, 1988-89, and 1992-93.

${ }^{4}$ Mahmood (1981) also found this effect to be negative for the period 1972-76. 
different exports according to their share in the total value of exports. Cotton, cotton fabrics, textile yarn and thread, and articles of textile materials ranked between 1 and 5 during the period under study. All these commodities have quite significant negative CCE in Table 2. Another interesting outcome in Table 2 is the change of sign (from negative to positive) of CCE for rice from 1984-85-1988-89 to 1988-891992-93 period. This result is due to decreasing share of rice in the total value of exports. Another noticeable result for CCE in Table 2 is the positive sign and increasing magnitude of the so called 'non-traditional' exports, such as Toys, games and sporting goods, fish and fish preparations, and medical instruments. However, these commodities have two digit ranks as shown in Table 3. The negative sign of overall CCE is due to larger magnitude of negative CCE for traditional compared to non-traditional exports. The big rise in the CCE (from -4.24 percent to -30.24 percent) is due to sustained concentration in the exports of traditional commodities. ${ }^{5}$

The market distribution effect (MDE) is small but positive for the first period and positive and large for the second period for the overall export growth as shown in Table 1. The positive sign suggests that Pakistan's exports are going to relatively rapidly growing markets. The large increase in the magnitude of MDE (more than

Table 1

\begin{tabular}{|c|c|c|}
\hline & 1984-85-1988-89 & 1988-89-1992-93 \\
\hline Total Change in Exports & $\begin{array}{l}1848.11 \\
(100.00)\end{array}$ & $\begin{array}{l}1702.69 \\
(100.00)\end{array}$ \\
\hline World Trade Effect & $\begin{array}{r}1200.50 \\
(64.96)\end{array}$ & $\begin{array}{l}703.42 \\
(41.31)\end{array}$ \\
\hline Commodity Composition Effect & $\begin{array}{l}-78.43 \\
(-4.24)\end{array}$ & $\begin{array}{c}-514.95 \\
(-30.24)\end{array}$ \\
\hline Market Distribution Effect & $\begin{array}{l}18.97 \\
(1.03)\end{array}$ & $\begin{array}{l}96.31 \\
(5.66)\end{array}$ \\
\hline Competitiveness Effect & $\begin{array}{l}707.07 \\
(38.26)\end{array}$ & $\begin{array}{r}1417.92 \\
(83.28)\end{array}$ \\
\hline
\end{tabular}

Source: United Nations (Various Issues); State Bank of Pakistan (Various Issues).

Note: Figures in the parentheses are percentage shares.

\footnotetext{
${ }^{5}$ Tariq and Najeeb (1995), in an econometric study, found the commodity concentration of exports in few commodities to be a major cause of exports earning instability in Pakistan.
} 
Table 2

Commodity-wise Analysis of Pakistan's Export-growth (Million U.S. Dollars)

\begin{tabular}{|c|c|c|c|c|c|c|c|c|c|c|c|c|c|}
\hline & Clothing & $\begin{array}{l}\text { Cotton } \\
\text { Fabrics }\end{array}$ & $\begin{array}{l}\text { Textile } \\
\text { Yarn \& } \\
\text { Thread }\end{array}$ & $\begin{array}{c}\text { Articles of } \\
\text { Textile } \\
\text { Materials }\end{array}$ & Cotton & $\begin{array}{l}\text { Leather } \\
\text { \& Manu- } \\
\text { factures } \\
\text { of Leather }\end{array}$ & Rice & $\begin{array}{c}\text { Floor } \\
\text { Coverings } \\
\text { \& Tapestries }\end{array}$ & $\begin{array}{l}\text { Synthetic } \\
\text { Fabrics }\end{array}$ & $\begin{array}{c}\text { Toys } \\
\text { Games \& } \\
\text { Sporting } \\
\text { Goods }\end{array}$ & $\begin{array}{c}\text { Fish \& } \\
\text { Fish } \\
\text { Preparations }\end{array}$ & $\begin{array}{c}\text { Medical } \\
\text { Instruments }\end{array}$ & Sum \\
\hline \multicolumn{14}{|c|}{ 1984-1988 } \\
\hline CIE & 308.02 & 230.47 & 288.06 & 171.22 & 510.01 & 110.10 & 88.62 & 86.30 & -9.23 & 23.01 & 25.97 & 15.57 & 1848.11 \\
\hline WTE & 141.57 & 162.93 & 167.21 & 121.86 & 165.01 & 121.12 & 52.74 & 110.57 & 33.00 & 35.34 & 52.77 & 36.39 & 1200.50 \\
\hline CCE & 70.43 & -48.37 & -35.34 & -10.61 & -115.20 & 26.16 & -37.76 & 31.39 & -2.27 & 20.40 & 14.20 & 8.53 & -78.43 \\
\hline MDE & -41.20 & 23.51 & 3.87 & -56.67 & -9.21 & 152.15 & 6.95 & -15.04 & -17.68 & 0.40 & -19.75 & -8.37 & 18.97 \\
\hline $\mathrm{CE}$ & 137.22 & 92.40 & 152.32 & 116.65 & 469.41 & -189.34 & 66.69 & -40.63 & -22.27 & -33.13 & -21.26 & -20.97 & 707.07 \\
\hline \multicolumn{14}{|c|}{ 1988-1992 } \\
\hline CIE & 640.19 & 545.84 & 383.23 & 276.63 & -390.21 & 66.93 & 32.38 & -22.87 & 94.80 & 37.44 & 5.78 & 32.56 & 1702.69 \\
\hline WTE & 102.23 & 91.11 & 104.53 & 67.90 & 151.45 & 54.63 & 32.49 & 46.83 & 6.49 & 13.99 & 19.10 & 12.67 & 703.42 \\
\hline CCE & 28.56 & -31.48 & -93.06 & -25.61 & -379.27 & -30.98 & 6.53 & -79.98 & 0.03 & 26.06 & 38.70 & 25.56 & -514.95 \\
\hline MDE & -14.41 & 73.81 & -38.62 & -20.51 & 66.80 & -0.87 & 44.69 & 4.73 & 6.78 & 3.59 & -34.20 & 4.51 & 96.31 \\
\hline CE & 523.81 & 412.39 & 410.39 & 254.85 & -229.19 & 44.16 & -51.33 & 5.55 & 81.50 & -6.20 & -17.82 & -10.17 & 1417.92 \\
\hline
\end{tabular}

Source: United Nations (Various Issues); State Bank of Pakistan (Various Issues).

Where,

CIE = Change in exports.

WTE $=$ World trade effect.

$\mathrm{CCE}=$ Commodity composition effect.

$\mathrm{MDE}=$ Market distribution effect.

$\mathrm{CE}=$ Competitiveness effect. 
Table 3

Ranking of Pakistani Exports According to their Shares in Total Exports

\begin{tabular}{lccc}
\hline & $1984-85$ & $1988-89$ & $1992-93$ \\
\hline Clothing & 6 & 3 & 1 \\
Cotton Fabrics & 1 & 4 & 2 \\
Textile Yarn and Thread & 3 & 2 & 3 \\
Articles of Textile Materials & 5 & 5 & 4 \\
Cotton & 2 & 1 & 5 \\
Leather and Manuf. of Leather & 12 & 6 & 6 \\
Rice & 4 & 7 & 7 \\
Floor Coverings and Tapestries & 8 & 8 & 8 \\
Synthetic Fabrics & 13 & 16 & 9 \\
Toys, Games and Sporting Goods & 11 & 10 & 10 \\
Fish and Fish Preparations & 10 & 9 & 11 \\
Medical Instruments & 12 & 12 & 12 \\
\hline
\end{tabular}

Source: State Bank of Pakistan (Various Issues).

five times) from 1984-85-1988-89 to 1988-89-1992-93 further suggests that Pakistan has improved her distribution of exports by concentrating into relatively faster growing economies. Table 2 shows that the sign of MDE changed from negative to positive for four commodities (cotton, floor coverings and tapestries, synthetic fabrics, and medical instruments), remained positive but improved for three commodities (cotton fabrics, rice, and toys, games and sporting goods) and remained negative but decreased for two commodities (clothing and articles of textile materials). All these factors improved the MDE. However, the sign of MDE changed from positive to negative for textile yarn and thread, and leather and leather manufactures, whereas, remained negative but increased for fish and fish preparations, resulting in off-setting the positive change in MDE to some extent. Table 4 explains how Pakistan has changed the market distribution of her exports. The export shares of Pakistan have increased enormously to the rapidly growing East Asian economies like Hong Kong, Korea, Singapore and Thailand, whereas, the shares have declined for relatively slowly growing economies like Sweden, Switzerland, and Saudi Arabia.

The CE is the largest contributor to the export growth from 1988-89 to 199293. As already mentioned, it is not straight forward to interpret the residual term, because it is determined by the interaction of many factors, such as supply and demand forces, price and non-price factors etc. ${ }^{6}$ The competitiveness effect for

${ }^{6} \mathrm{~A}$ regression analysis can be carried out to capture the effects of these factors on the competitiveness of exports by taking the CE of the $n$th commodity as dependent variable and real effective exchange rate of the $n$th commodity, produced quantity of the $n$th commodity and various dummy variables to capture the demand and supply side shocks as explanatory variables. For an application of this analysis, see Mahmood (1981). The application of this analysis for the recent years is suggested to get more insight about the competitiveness of Pakistan's exports. 
the

Table 4

Ranking of Trading Partners According to Pakistan's Export-shares

\begin{tabular}{lccc}
\hline Country & $1984-85$ & $1988-89$ & $1992-93$ \\
\hline U.S.A. & 1 & 1 & 1 \\
Germany & 5 & 4 & 2 \\
Hong Kong & 9 & 5 & 3 \\
U. K. & 3 & 3 & 4 \\
Japan & 2 & 2 & 5 \\
U.A.E. & 6 & 7 & 6 \\
Saudi Arabia & 4 & 12 & 7 \\
France & 14 & 10 & 8 \\
Italy & 7 & 6 & 9 \\
Korea & 29 & 13 & 10 \\
Netherlands & 19 & 16 & 11 \\
Canada & 24 & 20 & 12 \\
Bangladesh & 20 & 22 & 13 \\
Belgium & 25 & 24 & 14 \\
Spain & 26 & 15 & 15 \\
Australia & 23 & 19 & 16 \\
Singapore & 28 & 26 & 17 \\
Thailand & 38 & 14 & 18 \\
Sweden & 13 & 22 & 19 \\
Switzerland & 12 & 9 & 20 \\
Sri Lanka & 27 & 21 & 21 \\
India & 21 & 23 & 22 \\
\hline Sirce Ste Bar & & & \\
\hline
\end{tabular}

Source: State Bank of Pakistan (Various Issues).

overall exports is positive and quite significant for both the periods. Moreover, it has improved drastically from 1984-85-1988-89 to 1988-89-1992-93 (from 38.26 percent to 83.28 percent).

Table 2 shows that the competitiveness of the traditional exports, except rice and cotton, remained positive and improved enormously from first period to the second period. This resulted mainly due to comparative advantage of Pakistan in these commodities. The decreased competitiveness of cotton may have been resulted from increased protection by the USA and the European Community and the new competitive entrants of East Asia into cotton export market. ${ }^{7}$ Although the CE is

Although WTO has decided to remove the Multi-Fibre Arrangement in the coming decade, yet the process is quite slow and outcome is uncertain. Moreover, other forms of protection such as voluntary export restraints are still in action, which are more severe than tariffs. 
negative for the non-traditional exports, such as toys, games and sporting goods, medical instruments, and fish and fish preparations, yet it has decreased significantly in the second period. It reflects that Pakistan does not have comparative advantage in these products but is specialising by concentrating in their production.

The main factors for the increased competitiveness may be attributed to rapid devaluation, privatisation, liberalisation, and deregulation. After break down of the communist system in the planned economies, the capitalists system became more popular. Along with the formerly planned economies, the mixed economies like Pakistan also moved towards a market oriented open economic system by deregulating and liberalising the state owned institutions, financial organisations and international trade sector.

The export sector of Pakistan has been facing a dual effect of rapid devaluation and macroeconomic/political instability and high levels of corruption. On one hand, the sharp devaluation of Pakistan's currency (from 15.15 Rs/US\$ in 1984 to 30.85 Rs/US\$ in 1994) has made her exports very competitive. However, on the other hand, macroeconomic/political instability and corruption have dramatically raised the general price level, resulting in an increased cost of production for exportables. Therefore, as a net result, Pakistan's exports rose only marginally. The study of these interacting forces is a suggested area for future research.

\section{CONCLUSIONS AND POLICY RECOMMENDATIONS}

This paper analysed the export-growth of Pakistan for the periods: 1984-851988-89 and 1988-89-1992/93. The Constant Market Share Analysis is used to capture the contribution of various effects to the total change in exports. Our findings show that Pakistan has maintained her export share in the world market. The market distribution of Pakistan's exports has improved significantly and Pakistani exports have become more competitive over time. However, the positive contributions of above factors are off-set to a large extent by the concentration of exports in the traditional commodities whose world demand is very sluggish.

Despite some methodological flaws, the Constant Market Share Analysis produced interesting results. On the basis of our findings, the following policy recommendations are suggested. Firstly, the share of traditional export should be decreased and that of non-traditional exports should be increased in the total exports as the demand for the former is either stagnant or declining in the world market. ${ }^{8}$ Moreover, there is a further need to explore new areas of comparative advantage and increase the variety of exports by moving towards the exports of semi-manufactured and manufactured commodities from the raw commodities. Secondly, although

${ }^{8}$ Due to a drastic shift in the structure of international trade, manufactures now account for about 80 percent of world merchandise exports [Haque (1995)]. 
Pakistan has sharply adjusted the market distribution of her exports, there is still a room to explore new rapidly growing markets such as Indonesia, Malaysia, China and States of former Soviet Union. And, finally, policy-makers should maintain and improve the economic environment of the country by further moving towards a liberalised and an open economy and establishing macro-economic and political stability to make Pakistan's exports more and more competitive in the world market.

\section{REFERENCES}

Balassa, B. (1962) Recent Development in the Competitiveness of American Industry and Prospects for the Future. In U.S Congress, Joint Economic Committee, Factors Affecting the United States Balance of Payments, U. S. Government Printing Office. 27-54.

Fleming, J. M., and S. C. Tsiang (1958) Changes in Competitive Strength and Export Share of Major Industrial Countries. International Monetary Fund, Staff Papers 5.

Haque, Irfan ul (1995) Trade, Technology, and International Competitiveness. Washington, D. C.: The World Bank.

Hussain, I. (1974) Industrial Growth and Export Expansion: The Case of Pakistan. The Pakistan Development Review 13:2 308-324.

Leamer, E. E., and R. M. Stern (1970) Quantitative International Economics. Boston: Allyn and Bacon Inc. 171-183.

Little, I., T. Scitovsky and M. Scott (1970) Industry and Trade in some Developing Countries. London: Oxford University Press.

Mahmood, Zafar (1981) Changes in Export Shares and Competitive Strength in Pakistan. The Pakistan Development Review 20:4 399-415.

Richardson, J. D. (1971) Constant Market Share Analysis of Export Growth. Journal of International Economics 1:2 227-239.

State Bank of Pakistan (Various Issues) Export Receipts (1984-85, 1988-89, 199293). Statistics Department.

Stern, R. M. (1967) Foreign Trade and Economic Growth in Italy. New York: Wiley.

Tariq, A., and Q. Najeeb (1995) Export Earnings Instability in Pakistan. The Pakistan Development Review 34:4 1181-1189.

Tiwari, T. S. (1986) Constant Market Share Analysis of Export Growth: The Indian Case. The Indian Economic Journal 33:3 70-80.

Tyszynski, H. (1951) World Trade in Manufactured Commodities, 1899-1950. The Manchester School of Economics and Social Studies 19:3 272-304.

United Nations (Various Issues) Year Book of International Trade Statistics. 